\title{
Interleukin 2 Receptor Measurement
}

National Cancer Institute

\section{Source}

National Cancer Institute. Interleukin 2 Receptor Measurement. NCI Thesaurus. Code C158147.

The determination of the amount of interleukin 2 receptor present in a sample. 